\title{
PENENTUAN ANGKA KEPADATAN (DENSITY FIGURE) DAN ANGKA BEBAS JENTIK (ABJ) LARVA Aedes aegypti DI RW 02, KELURAHAN MARGAHAYU, KECAMATAN BEKASI TIMUR, KOTA BEKASI, JAWA BARAT
}

\author{
*Sumiati Bedah ${ }^{1)}$, Nico Hartandi ${ }^{1)}$ \\ ${ }^{1}$ Program Studi D III Analis Kesehatan, Fakultas Kesehatan, Universitas Mohammad Husni Thamrin \\ Correspondence author: Sumiati Bedah, sumiatibedah@yahoo.co.id, Jakarta, Indonesia
}

\begin{abstract}
ABSTRAK
World Health Organization (WHO) memperkirakan ada 390 juta infeksi dengue/tahun. Pada tahun 2016, di Indonesia tercatat sebanyak 204.171 kasus demam berdarah dengue (DBD) dengan jumlah kematian 1.598 orang. Jawa Barat merupakan provinsi dengan kasus DBD terbanyak. Di RW 02, Kelurahan Margahayu, Kecamatan Bekasi Timur, Kota Bekasi, Jawa Barat terdapat warga yang terkena DBD. Selain itu, kurangnya kegiatan 3M-Plus dan tidak adanya kegiatan kader juru pemantau jentik (jumantik) meningkatkan potensi penularan penyakit DBD di tempat tersebut. Tujuan penelitian ini adalah untuk menentukan tingkat kepadatan larva Aedes aegypti dan menentukan tingkat pengetahuan, sikap dan perilaku warga mengenai tempat penampungan air (TPA) dan 3M-Plus berdasarkan ada/tidaknya larva Ae. aegypti pada rumah warga, serta hubungan antara keduanya. Penelitian ini bersifat deskriptif analitik dengan pendekatan cross sectional. Seratus sampel rumah dipilih secara random sampling. Spesimen diambil dengan metode single larva. Data disajikan dalam tabel distribusi frekuensi dan dianalisis dengan uji chi-square. Hasil penelitian menunjukkan Angka Kepadatan (Density Figure $)=6$ (House Index $=38 \%$, Container Index $=22 \%$, Breteau Index $=50$ ), sehingga kepadatan larvanya tergolong tinggi. Angka Bebas Jentik (ABJ) sebesar $62 \%$, yang berarti belum memenuhi target $\mathrm{ABJ} \geq 95 \%$. Tingkat pengetahuan, sikap dan perilaku warga yang rumahnya tidak terdapat larva $A e$. aegypti tergolong baik dan berlaku sebaliknya. Terdapat hubugan antara keberadaan larva Ae. aegypti dengan pengetahuan $(p=0,022)$, sikap $(p=0,028)$ dan perilaku $(p=0,000)$ warga mengenai TPA dan kegiatan 3M-Plus. Berdasarkan hasil tersebut, disarankan agar warga lebih giat melakukan kegiatan 3M-Plus dan mengaktifkan kegiatan kader jumantik di RW 02.
\end{abstract}

Kata Kunci $\quad$ : Aedes aegypti, Density Figure, Angka Bebas Jentik

\section{ABSTRACT}

The World Health Organization (WHO) estimates there are 390 million dengue infections per year. In 2016, in Indonesia there were 204,171 cases of dengue fever (DBD) with 1,598 deaths. West Java is the province with the most DBD cases. In RW 02, Margahayu Village, East Bekasi District, Bekasi City, West Java there are residents affected by DBD. In addition, the lack of 3M-Plus activities and the absence of the activities of a cadre of monitoring agents (jumantik) increases the potential for transmission of DBD disease in the place. The purpose of this study is to determine the density level of Aedes aegypti larvae and determine the level of knowledge, attitude and behavior of citizens regarding water shelters (TPA) and 3M-Plus based on the absence of Ae larvae. aegypti on the people's home, as well as the relationship between the two. This research is descriptive of analytics with a cross sectional approach. One hundred sample houses are selected in random sampling. Specimens are taken by a single method of larvae. The data is presented in a frequency distribution table and analyzed with a chi-square test. The results showed Density Figure $=6$ (House Index $=38 \%$, Container Index $=$ $22 \%$, Breteau Index = 50), so the density of larvae is considered high. The Flick-Free Number (ABJ) is 62\%, which means it has not met the TARGET ABJ $\geq 95 \%$. The level of knowledge, attitude and behavior of the citizens whose houses there are no larvae of Ae. aegypti is relatively good and applies otherwise. There is a link between the presence of Ae larvae. aegypti with knowledge $(p=0.022)$, attitude $(p=0.028)$ and behavior $(p=$ $0.000)$ citizens regarding landfill and 3M-Plus activities. Based on these results, it is recommended that residents be more active in 3M-Plus activities and activate jumantik cadre activities in $R W 02$.

Keywords : Aedes aegypti, Density Figure, Flick Free Number.

Open Journal System (OJS): journal.thamrin.ac.id

http://journal.thamrin.ac.id/index.php/anakes/issue/view/33 


\section{PENDAHULUAN}

Penyakit dengue adalah infeksi virus yang ditularkan oleh nyamuk, terutama dari spesies Aedes aegypti. Penyakit dengue berat (demam berdarah dengue [DBD]) pertama kali dikenal pada tahun 1950-an selama epidemi demam berdarah di Filipina dan Thailand. Penyakit tersebut sekarang mewabah di lebih dari 100 negara di wilayah kerja World Health Organization (WHO).

Insiden DBD telah tumbuh secara dramatis di seluruh dunia dalam beberapa dekade terakhir. Satu perkiraan baru-baru ini menunjukkan 390 juta infeksi dengue per tahun. Studi lain tentang prevalensi dengue, memperkirakan 3,9 miliar orang di 128 negara berisiko terinfeksi virus Dengue. Tahun 2016 ditandai dengan wabah demam berdarah besar di seluruh dunia (WHO, 2018).

Wilayah Amerika, Asia Tenggara dan Pasifik Barat adalah yang paling terkena dampak serius dari penyakit dengue. Berdasarkan peta distribusi WHO (Gambar 1), selama tahun 20102016, terdapat rata-rata lebih dari 100.000 laporan kasus penyakit dengue setiap tahunnya dari ketiga wilayah tersebut (WHO, 2018, Epidemiology).

Di Indonesia kasus DBD pertama kali ditemukan di Surabaya pada tahun 1968. Sejak saat itu, penyakit tersebut menyebar luas ke seluruh Indonesia (Kementerian Kesehatan Republik Indonesia [Kemenkes RI] 2016).

Pada tahun 2016, tercatat sebanyak 204.171 kasus DBD dengan jumlah kematian 1.598 orang dari 34 provinsi yang ada di Indonesia. Jawa Barat berada di urutan pertama sebagai provinsi dengan jumlah kasus DBD terbanyak, yaitu tercatat 36.631 kasus DBD dengan jumlah kematian 270 orang (Kemenkes RI, 2017).

Di Jawa Barat peringkat ke-2 kota dengan kasus DBD terbanyak adalah Bekasi. Pada tahun 2016, di kota tersebut tercatat 3.813 kasus DBD dengan jumlah kematian 50 orang (Dinas Kesehatan [Dinkes] Provinsi Jawa Barat, 2017).

Terdapat 12 kecamatan di Bekasi, salah satu yang masuk ke dalam 5 besar kecamatan dengan kasus DBD terbanyak adalah Bekasi Timur. Pada tahun 2014, tercatat 115 kasus DBD terjadi di kecamatan tersebut (Dinkes Kota Bekasi, 2015). 
Tidak ada obat khusus untuk infeksi dengue dan juga tidak ada vaksin untuk mencegah infeksi dengue. Tindakan pencegahan terbaik adalah dengan menghilangkan tempat-tempat di mana nyamuk meletakkan telurnya, terutama wadah buatan yang dapat menampung air (Centers for Disease Control and Prevention [CDC], 2012).

Di Indonesia, tindakan pencegahan seperti hal di atas merupakan tindakan pengendalian vektor DBD yang dikenal sebagai upaya pemberantasan sarang nyamuk DBD (PSN-DBD) dalam bentuk kegiatan 3M-Plus (Direktorat Jenderal Pengendalian Penyakit dan Penyehatan Lingkungan [Ditjen P2PL], 2011: 59).

Untuk memantau kegiatan 3M-Plus, masing-masing puskesmas melakukan kegiatan pemantauan jentik berkala (PJB) di setiap desa atau kelurahan yang berada pada wilayah kerjanya. Dalam melakukan PJB, petugas puskesmas dibantu oleh kader juru pemantauan jentik (jumantik) di setiap RT (Ditjen P2PL, 2013: 26-28).

Untuk mengevaluasi hasil pengendalian vektor DBD, dapat dilakukan kegiatan surveilans vektor DBD. Salah satu metode surveilans vektor DBD yang sering dilakukan adalah survei larva. Kegiatan tersebut bertujuan untuk mendapatkan data-data kepadatan vektor DBD pada stadium larva, yaitu Angka Kepadatan (Density Figure) (meliputi House Index [HI], Container Index [CI], Breteau Index [BI]) dan Angka Bebas Jentik (ABJ). Survei larva biasanya dikombinasi dengan survei pengetahuan, sikap dan perilaku masyarakat (Ditjen P2PL, 2011: 62).

Menurut hasil penelitian Sari, dkk. (2017), didapatkan bahwa ada hubungan yang bermakna $(p=0,048)$ antara kepadatan larva Aedes sp. dengan kejadian DBD di Kel. Lubuk Buaya, Kec. Koto Tangah, Kota Padang. Selain itu, menurut hasil penelitian Nahdah, dkk. (2013) di Kel. Birobuli Selatan, Kota Palu, Sulawesi Tengah, didapatkan bahwa ada hubungan antara pengetahuan $(p=0,002)$, sikap $(p=0,032)$ dan perilaku $(p=0,035)$ masyarakat dalam melakukan kegiatan 3M-Plus dengan keberadaan larva Ae. aegypti.

Tempat penelitian penulis adalah RW 02 di Kelurahan Margahayu yang merupakan bagian dari Kecamatan Bekasi Timur, Kota Bekasi, Jawa Barat. 
Berdasarkan hasil wawancara pribadi (2018) sebelum penelitian dilakukan, menurut ketua RT 03 dan RT 04 di RW 02, penulis mendapatkan informasi bahwa ada warga di kawasan RT mereka yang terkena DBD dalam kurun waktu satu tahun terakhir.

Penulis juga mengamati bahwa masih kurangnya kegiatan 3M-Plus yang dilakukan oleh warga sekitar dan tidak adanya kegiatan kader jumantik pada setiap RT di daerah RW 02 . Kondisi-kondisi tersebut akan meningkatkan potensi penularan penyakit DBD di daerah RW 02.

Masalah-masalah yang telah dijelaskan di atas mendorong penulis untuk melakukan sebuah kegiatan penelitian. Salah satu penelitian yang dapat dilakukan penulis sebagai mahasiswa DIII Analis Kesehatan terhadap permasalahan yang ada adalah melakukan kegiatan surveilans vektor DBD dengan metode survei larva untuk menentukan Angka Kepadatan (Density Figure) dan Angka Bebas Jentik (ABJ) larva nyamuk Ae. aegypti, serta dikombinasi dengan survei tingkat pengetahuan, sikap dan perilaku warga di tempat penelitian.

\section{METODOLOGI PENELITIAN}

Penelitian ini termasuk ke dalam penelitian deskriptif analitik dengan pendekatan cross sectional. Kegiatan penelitian ini dilakukan di RW 02, Kelurahan Margahayu, Kecamatan Bekasi Timur, Kota Bekasi, Jawa Barat. Untuk pemeriksaan spesimen penelitian dilakukan di Laboratorium Biologi Universitas MH. Thamrin. Kegiatan penelitian ini dilakukan mulai dari 25-31 Juli 2018. Populasi dari kegiatan penelitian ini adalah semua rumah dan container yang berada di tempat penelitian. Menurut Ditjen P2PL (2011), survei larva dilakukan pada container di 100 rumah yang dipilih secara acak. Oleh karena itu, sampel dalam kegiatan penelitian ini adalah semua container di dalam dan di luar rumah yang berasal dari 100 rumah di tempat penelitian yang dipilih secara random sampling. Untuk mempermudah pemilihan sampel, karena di tempat penelitian terdapat 5 RT, untuk mendapatkan jumlah 100 sampel rumah, maka dipilih sebanyak 20 rumah secara acak dari masing-masing RT. Kegiatan survei larva dalam penelitian ini menggunakan metode single larva. Oleh karena itu, spesimen dalam kegiatan penelitian ini adalah satu ekor larva nyamuk yang diambil dari masing-masing sampel container. Karena terdapat keterbatasan waktu dan biaya penelitian, maka kriteria restriksi dalam kegiatan penelitian ini adalah sebagai berikut.

Kriteria Inklusi : 
Rumah : rumah yang didatangi oleh penulis di antara pukul 11.00-17.00 WIB, sedang ada penghuninya dan diizinkan untuk diperiksa oleh penghuni rumah tersebut.

Container : TPA untuk keperluan sehari-hari dan TPA bukan untuk keperluan sehari-hari.

Kriteria Eksklusi

Rumah : rumah yang didatangi penulis di antara pukul 11.00-17.00 WIB, sedang tidak ada penghuninya atau tidak diizinkan untuk diperiksa oleh penghuni rumah tersebut.

Container : TPA alamiah.

\section{Teknik Pengumpulan Data}

Mempersiapkan alat dan bahan untuk mengumpulkan data yang dibutuhkan dalam penelitian. Melakukan survei tempat yang akan menjadi tempat penelitian. Meminta izin kepada 5 Ketua RT dan Ketua RW 02 di Kelurahan Margahayu, Kecamatan Bekasi Timur, Kota Bekasi, Jawa Barat. Melakukan pemeriksaan sampel dan pengambilan spesimen, serta membagikan kuesioner kepada warga di tempat penelitian. Mencatat data yang didapat selama di tempat penelitian. Membawa spesimen ke laboratorium. Melakukan pemeriksaan spesimen di laboratorium. Mencatat data spesies yang didapat dari hasil identifikasi.

Analisis Data dilakukan dua cara analisis univariat dan analisis bivariat.

\section{HASIL DAN PEMBAHASAN}

\section{Hasil}

\section{Angka Kepadatan (Density Figure) (HI, CI, BI) dan Angka Bebas Jentik (ABJ) Larva} Ae. aegypti

Tabel 1

Distribusi Frekuensi Keberadaan Larva Nyamuk Berdasarkan Spesiesnya pada Container dan Rumah di RW 02,

Kel. Margahayu, Kec. Bekasi Timur, Kota Bekasi, Jawa Barat

\begin{tabular}{cccccc}
\hline $\begin{array}{c}\text { Keberadaan } \\
\text { Larva }\end{array}$ & \multirow{2}{*}{ Spesies } & \multicolumn{2}{c}{ Container } & \multicolumn{2}{c}{ Rumah } \\
& Ae.aegypti & 50 & 21,55 & 38 & 38 \\
Positif & Ae.albopictus & 1 & 0,43 & & $\mathbf{n}$ \\
Negatif & & 181 & 78,02 & 62 & 62 \\
\hline & Total & $\mathbf{2 3 2}$ & $\mathbf{1 0 0}$ & $\mathbf{1 0 0}$ & $\mathbf{1 0 0}$ \\
\hline \hline & & & & \\
Open Journal System (OJS): journal.thamrin.ac.id \\
http://journal.thamrin.ac.id/index.php/anakes/issue/view/33
\end{tabular}


Dari Tabel 3 dapat diketahui bahwa dari 232 container yang diperiksa, 50 container (21,55\%) terdapat larva Ae. aegypti, 1 container (0,43\%) terdapat larva Ae. albopictus dan 181 container $(78,02 \%)$ tidak terdapat larva nyamuk. Selain itu, dapat juga diketahui bahwa dari 100 rumah yang diperiksa, 38 rumah (38\%) terdapat larva Ae. aegypti dan 62 rumah (62\%) tidak terdapat larva Ae. aegypti.

Untuk mengetahui letak dan jenis container yang dominan terdapat larva Ae. aegypti, dapat dilihat pada Tabel 7 dan 8 pada Lampiran 2 dan 3.

Dari data pada Tabel 3, setelah dihitung berdasarkan cara ukur dan alat ukur masing-masing parameter, didapatkan nilai Angka Kepadatan (Density Figure) sebesar 6 (HI =38\%, CI = $22 \%, \mathrm{BI}=50)$ dan Angka Bebas Jentik (ABJ) sebesar 62\%.

\section{Tingkat Pengetahuan, Sikap dan Perilaku Warga}

Tabel 2

Distribusi Frekuensi Tingkat Pengetahuan, Sikap dan Perilaku Warga Mengenai TPA dan Kegiatan 3M-Plus di RW 02,

Kel. Margahayu, Kec. Bekasi Timur, Kota Bekasi, Jawa Barat

\begin{tabular}{|c|c|c|c|c|c|}
\hline \multirow{3}{*}{ Variabel } & \multicolumn{4}{|c|}{ Keberadaan Larva } & \multirow{3}{*}{$\begin{array}{c}\text { Total } \\
\mathrm{n}\end{array}$} \\
\hline & \multicolumn{2}{|c|}{ Positif } & \multicolumn{2}{|c|}{ Negatif } & \\
\hline & $\mathbf{n}$ & $\%$ & $\mathbf{n}$ & $\%$ & \\
\hline \multicolumn{6}{|c|}{ Pengetahuan } \\
\hline Baik & 10 & 25,64 & 29 & 74,36 & 39 \\
\hline Cukup & 15 & 37,50 & 25 & 62,50 & 40 \\
\hline Kurang & 13 & 61,90 & 8 & 38,10 & 21 \\
\hline \multicolumn{6}{|l|}{ Sikap } \\
\hline Baik & 16 & 28,57 & 40 & 71,43 & 56 \\
\hline Cukup & 22 & 50,00 & 22 & 50,00 & 44 \\
\hline Kurang & 0 & 0 & 0 & 0 & 0 \\
\hline \multicolumn{6}{|l|}{ Perilaku } \\
\hline Baik & 5 & 20,83 & 19 & 79,17 & 24 \\
\hline Cukup & 18 & 31,03 & 40 & 68,97 & 58 \\
\hline Kurang & 15 & 83,33 & 3 & 16,67 & 18 \\
\hline Total & 38 & 38 & 62 & 62 & 100 \\
\hline
\end{tabular}

Open Journal System (OJS): journal.thamrin.ac.id 
Dari Tabel 4 dapat dilihat bahwa untuk variabel pengetahuan, rumah yang terdapat larva Ae. aegypti, mayoritas warganya berada di tingkat pengetahuan kurang $(61,90 \%)$. Rumah yang tidak terdapat larva Ae. aegypti, mayoritas warganya berada di tingkat pengetahuan baik $(74,36 \%)$.

Untuk variabel sikap, rumah yang terdapat larva Ae. aegypti, mayoritas warganya berada di tingkat sikap cukup (50,00\%). Rumah yang tidak terdapat larva Ae. aegypti, mayoritas warganya berada di tingkat sikap baik (71,43\%).

Untuk variabel perilaku, rumah yang terdapat larva Ae. aegypti, mayoritas warganya berada di tingkat perilaku kurang (83,33\%). Rumah yang tidak terdapat larva Ae. aegypti, mayoritas warganya berada di tingkat perilaku baik $(79,17 \%)$.

\section{Hubungan antara Keberadaan Larva Ae. aegypti dengan Tingkat Pengetahuan, Sikap dan Perilaku Warga}

Tabel 3

Hubungan antara Keberadaan Larva Ae. aegypti dengan Tingkat Pengetahuan, Sikap dan Perilaku Warga

Mengenai TPA dan Kegiatan 3M-Plus di RW 02,

Kel. Margahayu, Kec. Bekasi Timur, Kota Bekasi, Jawa Barat

Variabel

Chi-Square Test

\begin{tabular}{cccc} 
& p-value & Chi Hitung & Chi Tabel \\
\hline Pengetahuan & $0,022^{*}$ & 7,6262 & 5,9915 \\
Sikap & $0,028^{*}$ & 4,8023 & 3,8415 \\
Perilaku & $0,000^{*}$ & 19,898 & 5,9915 \\
\hline
\end{tabular}

* : p-value $<0,05$

Dari Tabel 5 dapat diketahui bahwa hasil analisis menggunakan uji chi-square didapatkan nilai $p$-value untuk pengetahuan $(0,022)$, sikap $(0,028)$ dan perilaku $(0,000)$ semuanya kurang dari $0,05(p \leq 0,05)$. Nilai chi hitung untuk pengetahuan $(7,6262)$, sikap $(4,8023)$ dan perilaku 
$(19,898)$ semuanya juga lebih besar daripada nilai chi tabelnya. Hal-hal tersebut menunjukkan adanya hubungan antara keberadaan larva Ae. aegypti dengan tingkat pengetahuan, sikap dan perilaku warga mengenai TPA dan kegiatan 3M-Plus.

\section{Pembahasan}

\section{Angka Kepadatan (Density Figure) (HI, CI, BI) dan Angka Bebas Jentik (ABJ) Larva Ae. aegypti}

Dalam penelitian ini, ditemukan hanya satu genus larva nyamuk, yaitu Aedes sp. Hasil yang hampir sama dapat ditemukan dalam hasil penelitian yang dilakukan oleh Budiyanto (2012) di Kec. Baturaja Timur, Kabupaten Ogan Komering Ulu, Sumatra Selatan. Dalam penelitiannya, selain genus Aedes sp., ditemukan juga genus Culex sp. Budiyanto (2012) menjelaskan bahwa hal tersebut terjadi karena ada beberapa container yang air di dalamnya merupakan air sumur yang dialirkan dengan pompa ke container tersebut.

Hasil penelitian juga menunjukkan bahwa lebih dominan larva Ae. aegypti yang ditemukan daripada larva Ae. albopictus. Hasil tersebut sama dengan hasil penelitian yang dilakukan oleh Sari, dkk. (2017) di Kel. Lubuk Buaya, Kec. Koto Tangah, Kota Padang. Menurut Sari, dkk. (2017), nyamuk Ae. aegypti tersebar luas terutama di wilayah perkotaan. Sedangkan Ae. albopictus lebih banyak ditemukan di wilayah pinggiran kota dan pedesaan. Hasil penelitian yang didapatkan sesuai dengan pernyataan tersebut karena RW 02, Kel. Margahayu, Kec. Bekasi Timur, Kota Bekasi, Jawa Barat merupakan wilayah perkotaan. Selain itu, penulis juga berasumsi bahwa larva Ae. aegypti lebih banyak ditemukan karena dalam penellitian ini tidak dilakukan pemeriksaan terhadap TPA alamiah, di mana tempat tersebut merupakan tempat yang lebih disukai oleh Ae. albopictus.

Didapatkan hasil penelitian yang menunjukkan bahwa persentase tertinggi untuk letak container yang terdapat larva Ae. aegypti adalah persentase dari container yang berada di luar rumah. Penulis berasumsi bahwa hasil tersebut didapatkan karena jumlah container di luar rumah lebih sedikit dibandingkan dengan jumlah container di dalam rumah, namun jumlah container di luar rumah yang terdapat larva hampir mencapai setengah jumlah container di luar rumah yang diperiksa. Hasil tersebut berbeda dengan hasil penelitian yang dilakukan oleh Sari, dkk. (2017), di mana jumlah container di dalam rumah lebih banyak yang terdapat larva 
dibandingkan dengan yang di luar rumah. Menurut Sari, dkk. (2017), nyamuk Ae. aegypti lebih menyukai tempat perindukan di dalam rumah dibandingkan di luar rumah dan suka hinggap pada pakaian yang digantung untuk beristirahat dan bersembunyi.

Didapatkan juga hasil penelitian yang menunjukkan bahwa ada 5 jenis container yang terdapat larva Ae. aegypti dengan persentase tertinggi, yaitu tatakan pengering piring, pinggiran pot, pot tanaman air, akuarium bekas dan gentong. Penulis berasumsi hasil tersebut didapatkan karena container-container tersebut ditemukan dalam jumlah yang sedikit dan masing-masing dari jenis container tersebut jumlah container yang terdapat larva sama dengan atau hampir sama dengan jumlah container yang diperiksa. Selain itu, penulis juga berasumsi bahwa hasil tersebut memang hal yang wajar karena (1) tatakan pengering piring dan pinggiran pot termasuk jenis container yang luput dari kegiatan menguras; (2) gentong merupakan jenis container yang relatif besar dan sulit untuk membersihkannya; (3) pot tanaman air termasuk jenis container yang tidak bisa dikuras dan (4) akuarium bekas yang ditemukan dibiarkan airnya tetap penuh setelah ikan di dalamnya sudah tidak ada, jadi container-container tersebut sudah mengandung air dalam jangka waktu yang lama dan mungkin sudah banyak tumbuh mikroorganisme yang menjadi makanan larva nyamuk.

Dalam teori-teori yang ada dan penelitian-penelitian yang dilakukan, salah satunya penelitian yang dilakukan oleh Sari, dkk. (2017), dikatakan bahwa tempat yang disukai oleh nyamuk vektor DBD adalah TPA yang mengandung air bersih, tidak terkena sinar matahari langsung dan nyamuk Ae. aegypti tidak dapat hidup di air yang berhubungan langsung dengan tanah. Namun, dalam penilitian ini, ditemukan adanya larva nyamuk Ae. aegypti yang hidup di dalam container (pot tanaman air) yang berada di luar rumah (terkena sinar matahari langsung) dan airnya berhubungan langsung dengan tanah. Hal yang serupa dapat ditemukan pada hasil penelitian Wurisastuti (2013) di Loka Litbang P2B2 Baturaja, di mana hasil penelitiannya menujukkan nyamuk Ae. aegypti dapat bertelur di air tercemar seperti campuran air dengan kotoran sapi dan campuran air dengan tanah. Wurisastuti (2013) mengatakan bahwa hal tersebut membuktikan adanya perubahan perilaku nyamuk Ae. aegypti dalam memilih tempat perindukan dan beradaptasi dengan lingkungan, di mana bila tidak menemukan tempat perindukan dari air bersih maka nyamuk Ae. aegypti dapat beralih ke tempat lain yang tercemar. Wurisastuti (2013) menjelaskan bahwa hal tersebut diduga terjadi karena sifat dari campuran air dengan kotoran sapi atau tanah akan memisah kembali, zat 
terlarut akan mengendap ke bawah terpisah dengan pelarutnya, jadi bagian atas larutan tetap terlihat jernih namun kandungan kimiawi yang terkandung tetap bercampur dengan air.

Dalam penelitian ini, didapatkan nilai Angka Kepadatan (Density Figure) sebesar 6 (HI = $38 \%, \mathrm{CI}=22 \%, \mathrm{BI}=50)$ sehingga kepadatan larvanya dikategorikan sebagai kepadatan tinggi. Serupa dengan penelitian yang dilakukan oleh Sari, dkk. (2017), di mana kepadatan larva di tempat penelitiannya tergolong kepadatan tinggi. Sari, dkk. (2017) menyatakan bahwa jika suatu tempat memiliki nilai $\mathrm{HI} \geq 10 \%, \mathrm{CI} \geq 5 \%, \mathrm{BI} \geq 50$ dan $\mathrm{DF}>5$, maka tempat tersebut berisiko tinggi untuk penularan DBD dan berpotensi untuk mengalami KLB. Selain itu, bedasarkan wawancara tambahan yang dilakukan penulis, didapatkan bahwa ada rumah yang penghuninya pernah terkena DBD dan rumah tersebut saat diperiksa terdapat larva $A e$. aegypti. Hal tersebut akan menambah risiko transmisi penyakit DBD di tempat penelitian penulis.

Hasil ABJ dalam penelitian ini sebesar 62\%. Hasil tersebut dikatakan tidak memenuhi target $\mathrm{ABJ} \geq 95 \%$. Hasil yang sama juga didapatkan dalam penelitian yang dilakukan oleh Murdani, dkk. (2015), di mana ABJ di Kec. Purwoharjo, Kabupaten Banyuwangi, Jawa Timur kurang dari 95\%. Murdani, dkk. (2015) menyatakan bahwa apabila ABJ $\geq 95 \%$ diharapkan penularan DBD dapat dicegah atau dikurangi.

\section{Tingkat Pengetahuan, Sikap dan Perilaku Warga}

Hasil penelitian menunjukkan rumah yang tidak terdapat larva Ae aegypti, mayoritas warganya berada di tingkat pengetahuan baik, sikap baik dan perilaku baik. Penulis berasumsi bahwa hal tersebut sudah benar, di mana tingkat pengetahuan yang baik akan mendorong warga memiliki tingkat sikap yang baik dan kedua hal tersebut akan mendorong warga memiliki tingkat perilaku yang juga baik sehingga rumah warga tersebut terbebas dari larva nyamuk. Hal tersebut juga berlaku sebaliknya pada rumah yang terdapat larva Ae. aegypti.

\section{Hubungan antara Keberadaan Larva Ae. aegypti dengan Tingkat Pengetahuan, Sikap dan Perilaku Warga}

Hasil uji statistik menunjukkan bahwa ada hubungan antara keberadaan larva Ae. aegypti dengan tingkat pengetahuan, sikap dan perilaku warga mengenai TPA dan kegiatan 3M-Plus. Hasil tersebut serupa dengan hasil penelitian yang dilakukan oleh Nahdah, dkk. (2013) di Kel. 
Birobuli Selatan, Kota Palu, Sulawesi Tengah. Dapat dilihat dalam penelitiannya juga bahwa rumah yang tidak terdapat larva nyamuk, tingkat pengetahuan, sikap dan perilaku warganya baik dan berlaku sebaliknya pada rumah yang terdapat larva Ae. aegypti.

Hal tersebut membuat penulis berasumsi bahwa benar ada hubungan antara keberadaan larva nyamuk Ae. aegypti dengan tingkat pengetahuan, sikap dan perilaku warga mengenai TPA dan kegiatan 3M-Plus, di mana hubungannya adalah semakin tinggi tingkat pengetahuan, sikap dan perilaku warga maka rumah atau tempat tinggal warga tersebut semakin terbebas dari larva nyamuk.

\section{SIMPULAN}

Kesimpulan dari penelitian yang dilakukan terhadap 100 rumah, 232 container dan 232 spesimen larva nyamuk di RW 02, Kelurahan Margahayu, Kecamatan Bekasi Timur, Kota Bekasi, Jawa Barat adalah sebagai berikut. Nilai Angka Kepadatan (Density Figure) larva Ae. aegypti sebesar $6(\mathrm{HI}=38 \%, \mathrm{CI}=22 \%, \mathrm{BI}=50)$, sehingga kepadatan larvanya tergolong tinggi. Nilai Angka Bebas Jentik (ABJ) larva Ae. aegypti sebesar 62\%, sehingga tempat tersebut belum memenuhi target $\mathrm{ABJ} \geq 95 \%$. Tingkat pengetahuan, sikap dan perilaku warga yang rumahnya tidak terdapat larva Ae. aegypti tergolong baik. Sedangkan, warga yang rumahnya terdapat larva Ae. aegypti, tingkat pengetahuan, sikap dan perilakunya tergolong kurang. Ada hubungan antara keberadaan larva nyamuk Ae. aegypti dengan tingkat pengetahuan, sikap dan perilaku warga mengenai TPA dan kegiatan 3M-Plus, di mana hubungannya adalah semakin tinggi tingkat pengetahuan, sikap dan perilaku warga maka rumah atau tempat tinggal warga tersebut semakin terbebas dari larva nyamuk.

\section{UCAPAN TERIMA KASIH}

Penulis mengucapkan terima kasih kepada Warga RW 02, Kelurahan Margahayu, Kecamatan Bekasi Timur, Kota Bekasi, Jawa Barat, Kepala Laboratorium B Fakultas Kesehatan Universitas Mh.Thamrin Jakarta dan Prodi D III Analis Kesehatan Fakultas Kesehatan Universitas MH Thamrin. dalam penelitian ini.

\section{DAFTAR PUSTAKA}

1. Budiyanto, A. 2012. Perbedaan Warna Kontainer Berkaitan dengan Keberadaan Jentik Aedes aegypti di Sekolah Dasar. Jurnal Biotek Medisiana Indonesia. 1(2): 65-71. 
2. CDC. 2012. Dengue - Frequently Asked Questions. https://www.cdc.gov/ dengue/faqfacts/index.html. Diakses 16 Juli 2018.

3. Dinkes Kota Bekasi. 2015. Profil Kesehatan Kota Bekasi Tahun 2014. Bekasi: Dinkes Kota Bekasi.

4. Dinkes Provinsi Jawa Barat. 2017. Profil Kesehatan Jawa Barat Tahun 2016. Bandung: Dinkes Provinsi Jawa Barat.

5. Ditjen P2PL. 2011. Modul Pengendalian Demam Berdarah Dengue. Jakarta: Ditjen P2PL.

6. Ditjen P2PL. 2013. Buku Saku Pengendalian Demam Berdarah Dengue untuk Pengelola Program DBD Puskesmas. Jakarta: Ditjen P2PL.

7. Frida. 2008. Mengenal Demam Berdarah Dengue. Jakarta: CV Pamularsih.

8. Kemenkes RI. 2016. InfoDATIN - Situasi DBD di Indonesia. Jakarta: Kemenkes RI.

9. Kemenkes RI. 2017. Profil Kesehatan Indonesia Tahun 2016. Jakarta: Kemenkes RI.

10. Murdani, A.P., dkk. 2015. Pemetaan Kejadian DBD Berdasarkan Angka Bebas Jentik dan Jenis Infeksi Virus Dengue. Jurnal Keperawatan dan Kebidanan-Stikes Dian Husada Mojokerto: 30-43.

11. Nahdah, dkk. 2013. Hubungan Perilaku 3M Plus dengan Densitas Larva Aedes aegypti di Kelurahan Birobuli Selatan, Kota Palu, Sulawesi Tengah. http://repository.unhas.ac.id/bitstream/handle/123456789/5658/JURNAL\%20NAHDA. pdf. Diakses 16 Juli 2018.

12. Prianto, J., dkk. 2004. Atlas Parasitologi Kedokteran. Jakarta: Gramedia Pustaka Utama.

13. Pusarawati, S., dkk. 2014. Atlas Parasitologi Kedokteran. Jakarta: Penerbit Buku Kedokteran EGC.

14. Sari, I.P., dkk. 2017. Hubungan Kepadatan Larva Aedes sp. dengan Kejadian Demam Berdarah Dengue di Kelurahan Lubuk Buaya, Kecamatan Koto Tangah, Kota Padang. Jurnal Kesehatan Andalas. 6(1): 41-48.

15. Soedarto. 1992. Entomologi Kedokteran. Jakarta: Penerbit Buku Kedokteran EGC.

16. Soejoto dan Soebari. 1996. Materi Kuliah Parasitologi Medik Jilid II (Entomologi). Surakarta: Akademi Analis Kesehatan Surakarta.

17. Staf Pengajar Bagian Parasitologi FKUI. 2000. Parasitologi Kedokteran. Jakarta: Balai Penerbit FKUI.

18. Staf Pengajar FKUI. 1994. Mikrobiologi Kedokteran Edisi Revisi. Jakarta: Binarupa Aksara.

19. Susanna, D. dan Terang Uli J. Sembiring. 2011. Entomologi Kesehatan (Artropoda Pengganggu Kesehatan dan Parasit yang Dikandungnya). Jakarta: Universitas Indonesia (UI-Press).

20. WHO. 2018. Dengue and Severe Dengue. http://www.who.int/en/news-room/factsheets/detail/dengue-and-severe-dengue. Diakses 16 Juli 2018.

21. WHO. 2018. Epidemiology. http://www.who.int/denguecontrol/epidemiolo gy/en/. Diakses 16 Juli 2018. 
Wurisastuti, T. 2013. Perilaku Bertelur Nyamuk Aedes aegypti pada Media Air Tercemar. Jurnal Biotek Medisiana Indonesia. 2(1): 25-31. 